\title{
Differences in Factors Responsible for Lateness at School by Male and Female Learners in Selected Schools in Soshanguve Township, South Africa
}

\author{
Mary Motolani Olowoyo, Sam Ramaila and Lydia Mavuru \\ Department of Science and Technology Education, Faculty of Education, \\ University of Johannesburg, South Africa \\ https://orcid.org/0000-0003-0332-8979 \\ https://orcid.org/0000-0002-7351-477X \\ https://orcid.org/0000-0001-9099-0746
}

\begin{abstract}
Late coming is an endemic problem in South African schools and has become increasingly difficult to eradicate. It has been identified as a major factor affecting learner academic performance and pass rate within the broader South African school context. This study examined factors that influence the late coming of both male and female learners in selected schools in the Soshanguve Township with a view to assessing their impact on learner academic performance and emotional stability within the school environment. The study adopted an exploratory descriptive survey design, involving eighty purposively selected learners as participants. Quantitative data was collected through the administration of a survey questionnaire and result analysed using ANOVA and the paired sample t-test. The findings showed that factors such as mode of transportation to school, geographical location of school/homes, learner involvement in household chores, watching television at night, sleeping late and child care responsibilities are predominantly responsible for the late coming. The study further revealed that male learners were more often late for school as compared to female learners. Late coming of female learners hinged to a large degree on domestic factors while the late coming of male learners depended on attitude and peer pressure. The male learners were reluctant to change the habit as it was not perceived to be an emotional disturbance while female learners were amenable to habit change.
\end{abstract}

Keywords: academic performance; attitudes; late coming; peer pressure; township 


\section{Introduction}

Late coming has become a major problem globally and from a study conducted by the Organisation for Economic Co-operation and Development (OECD, 2013) which interviewed students from many countries, it was found that most students arrived at school after lessons had already started (OECD, 2013; Nonkonana \& Kwenda, 2019). Lateness generally refers to a situation in which an individual reports at a place later than the scheduled, appropriate or agreed time (Onoyase, 2017; Adegunju et al., 2019). Within the school context, lateness may be defined as arrival at school by learners after the official opening hours and may be further be extended to arriving late at scheduled normal timetable for lectures or classes to begin (Maile \& Olowoyo, 2017). Owing to the rate of late coming in high schools, lateness is perceived to stifle development and may negatively affect student academic performance (Maile \& Olowoyo, 2017; McKeever \& Clark, 2017; Warne et al., 2020). It can lead to serious consequences such as missing out on lessons, failing, disrupting the class, school dropout, time wasting and extension of the period spent by learners in schools (Onoyase, 2017).

The regular attendance of school by students is necessary in preparing the students towards reaching their full potential (Agboblie \& Mensah, 2016). However, lateness to school has defeated the purpose of the school establishment which, inter alia, includes educating and training students within a scheduled and pre-arranged programme with a view to preparing students' entrance into a successful life through punctuality (Agboblie \& Mensah, 2016). The policy on child education in most countries dwells on 'accessibility' to good education and theoretically, access could encompass educational quality, process, outcomes as well as inclusivity, equity and sustainability (Consortium for Research into Educational Access, Transitions and Equity [CREATE], 2012). A learner who is often late to school would not fulfil roles such as engagement with peers, engagement with good quality teaching and learning in the classroom (Humphrey et al., 2015).

Various countries have put different measures in place to curb lateness in high schools. For instance, Jumare et al. (2015) in a study conducted in Nigeria reported that the principal and parents are responsible for administering punishments to late comers but also for working together as a team to curb lateness to schools. Similarly in South Africa, there is a circular on how to manage late coming from the Department of Basic Education and the management of late coming in schools rests on the School Management Team and the parents (DBE, 2009). In these policies schools should have systems and procedures for ensuring regular school attendance, punctuality and monitoring lateness and poor school attendance (Department of Education, 2018). Before the dawn of democracy in South Africa, the school attendance policy was implemented by teachers under the guidance of principals. Learners who arrived at school late were usually locked outside the gate (Ngubane \& Mkhize, 2018). However, the current school policy in South Africa does not make provision for such practices anymore (Whole School Evaluation Policy, 2002). Some teachers who thought teaching could not be possible without corporal punishment met stiff oppositions from students who challenge the classroom 
authority (Ngubane \& Mkhize, 2018). The new law introduced school level codes of conduct and gave parents an unprecedented involvement in school affairs. When learners contravene the rules, parents are engaged to provide guidance and support to inculcate appropriate behaviour. Thus teachers in South Africa find it extremely difficult to administer punishment to learners and feel helpless (Ngubane \& Mkhize, 2018). In Nigeria, the use of corporal punishment is often treated as an integral part of education, occupying a place in schools' teaching. However, bullying in any form is not allowed (Jonathan et al., 2017). Teachers often used corporal punishment to make learners conform to the norms of the school and this may at times have involved gentle striking either across the buttocks or on the hand (Jonathan et al., 2017). In the current study, Shoshanguve is a township in the northern part of Pretoria with several reports on the news media of students coming to school late and roaming about on the streets (SABC 2 News, 2016).

\section{Literature Review}

Several studies have reported on the factors responsible for causing late coming among high school learners (Jumare et al., 2015; Onoyase, 2017: Maile \& Olowoyo, 2017). A report compiled by Adegunju et al. (2019) revealed that Nigerian teachers ascribed late coming to poor preparation for school, going to bed late, travelling distance between school and home, level of poverty, peer pressure, and single parenthood. Other studies identified household chores especially for girls from poorer, more rural households, who also often have to look after younger siblings or sick relatives as a major factor (Nonkonana \& Kwenda, 2020; Adegunju, 2019). Maile and Olowoyo (2017) highlighted the lack of teaching materials, mode of delivery, first lesson of the day, and structure of the schools as reasons for late coming and absenteeism. The factors highlighted by Maile and Olowoyo (2017) are largely perceived as a source of demotivation for young people. At an initial pragmatic level, bullying and teasing have also been observed to affect both boys and girls (UNICEF, 2012). As noted by Jumare (2015), mode of transport is one of the factors contributing to late coming at schools.

Developing and preparing learners for the future requires regular school attendance by both teachers and learners to ensure that optimal training takes place. However, developing and preparing learners for the future may be hampered by late coming, truancy, inability to read and lack of consultation opportunities with teachers (Oghuvbu, 2012). Regular school attendance provides opportunities to learners to realize their full potential through skills development. Sultana and Rashid (2013) posit that punctuality and time management problems among learners in schools are related to late coming. Agboblie and Mensah (2016) and Maile and Olowyo (2017) postulate that recurrent lateness at schools may not only affect the academic performance of learners, but could also create serious problems for individuals in later life if not checked.

Persistent late coming by learners at schools has been linked to the falling standards of education globally (Chujor, 2014). In fact, scholars have suggested that for any school to succeed in discharging its basic duty of training learners 
there should be some form of discipline and management. For instance, Jonathan et al. (2017) assert that discipline is necessary because it sets a congenial atmosphere needed for teaching and learning. The impact of late coming is also felt in society because education is seen as a vital tool that serves as a major driving factor for social and economic transformation of a nation and this may later result into progress and development of the society.

Late coming has increasingly become a perennial problem in many South African schools (Nonkonana \& Kwendu, 2020). In South Africa, as reported by Nonkonana and Kwendu (2020), 20\% of the South African learners report to school when the school has already started. Recently, the South African government lamented the adverse impact of perpetual late coming and learner absenteeism on schooling (DBE, 2009). Equal Education, which is a voluntary organization, also staged a rally to sensitize learners about the detrimental impact of late coming on teaching and learning (Equal Education, 2018). The rally was led by learners with the aim of assisting schools to instil a sense of punctuality among learners. According to the National Staff Reporter (2016), the late coming of learners in South Africa could also be attributed to the teachers' absenteeism and coming to work late. A previous study by Maile and Olowoyo (2017) showed that coming to school late has been a norm in the area and also this is observed in both males and females. However, there are factors that are responsible for this phenomenon. As late coming remains a pervasive problem at South African schools, there is a critical need to examine the factors influencing the late coming of male and female learners in diverse school contexts.

The empirical investigation is accordingly guided by the following main research question:

What are the differences in factors that influence the late coming of male and female learners in Shoshanguve Township schools in South Africa?

To answer the main research question, the following sub-questions were formulated:

- What are the differences in factors that influence the late coming of male and female learners at the selected schools in Soshanguve Township?

- To what extent do household chores, school governance, scholar transport and distance, and peer pressure influence late coming?

- What is the role of gender in the manifestation of late coming at selected schools in Soshanguve Township?

\section{Theoretical framework}

The study framework was built around the social efficiency theoretical framework and learner-centred ideology. The social efficiency ideology places more emphasis on the capability of the child to fill social needs of society while the learner-centred ideology looks at the needs and interests of the learner. This becomes important in understanding learners' background which is central to the learning and needs of the students and can be incorporated in the learning experience (Armend, 2017). As mentioned earlier, if students perpetually come to school late, it may translate to later years, where their sense of responsibility 
in the society will be reduced. However, there is a need to understand the reasons for lateness with a view to assisting the students which is in agreement with leaner-centred ideology. In the current study the individual refers to the male or female learners from the township schools in Soshanguve while their desired goals refer to their aspirations of passing high school examinations, probably continuing with tertiary studies and then being employed.

The aim of social efficiency theory is to design a curriculum that would optimize the social utility of each individual in a society with the aim of turning schools into "factories" where raw materials "students" are shaped and fashioned into products to meet the various demands of life (Bailey, 2015). The theory emphasizes that education should be used as an efficient tool to assist in shaping society. In addition, learners would be scientifically evaluated and educated towards their pre-determined role in society. The learner-centred ideology will provide consultations to the child and understanding their role in society will also speak to their attitude towards punctuality (Moate \& Cox, 2015). In essence, particular attention should be focused on the development of learners' emotional and behavioural qualities.

Drawing on the social efficiency theory, a determination of the variation in the factors that influence the late coming of male and female learners and in particular an analysis of how the same factors can impact on learners' behaviour (late coming) in different ways were undertaken in this study with the hope of finding solutions to the problem. Such solutions need to consider that the male and female learners live in a society where there are gender-ascribed roles and behaviours which are deeply entrenched. In this current study the knowledge about the factors that influence learners' late coming cannot be separated from the context (Rowe et al., 2013) in which the male and female learners are living.

The aim of social efficiency theory is to design a curriculum that would optimize the social utility of each individual in a society (De Lissovoy et al., 2014). Also with a learner-centred approach, the idea is to shift from a paradigm in which time is held constant, thereby forcing achievement to vary. It could also be designed specifically to meet the needs of the students and their communities by allowing students the time that each needs to reach proficiency (Moate \& Cox, 2015).

These two theories emphasize that education should be used as an efficient tool to assist in shaping the students which in turn affects society. In addition, learners would be scientifically evaluated, prepared and educated towards their pre-determined role in society. Understanding their role in society would also speak to their attitude towards punctuality. In essence, particular attention should be focused on the development of learners' emotional and behavioural qualities. Therefore, the study seeks to understand their attitudes towards lateness and concomitant factors.

\section{Research design and methodology}

The study adopted a mixed-method approach as part of an exploratory sequential mixed-methods design. A mixed-method research has the potential to advance theory and enhance the usefulness of research findings (McCrudden et al., 2019). An exploratory descriptive survey design makes provision for the 
determination and description of the situation and compares how sub-groups view a certain issue (Gay et al., 2011). An exploratory research design also provides opportunities for gathering information in an informal and unstructured manner. It further helps a researcher to build understanding about the problem of the research and to generate new ideas from the research (Swedberg, 2018). In this study, the researchers seek to understand the differences in factors that are responsible for late coming between males and females as previously alluded to in previous studies (Maile \& Olowoyo, 2017). In addition, an exploratory research design is not limited to one specific paradigm as it may use either qualitative or quantitative approaches (Swedberg, 2018). This was adopted in order to provide a full understanding of the problem, the relationships and to what extent these factors responsible for late coming among the students interviewed could be relevant among the respondents, thereby leading to data triangulation.

\subsection{Sampling}

The study involved eighty purposively selected learners from six selected schools in Soshanguve Township. Learners who participated in the study were selected based on the school attendance record as provided to the researchers by the school and these students were the perpetual late comers. Only learners who were reported to be perpetual late comers and who were willing to participate in the study were selected for the study. Soshanguve Township is geographically located in Pretoria in the Gauteng Province of South Africa. The participants were between the ages of 17 and 21 years old. Questionnaires were designed and distributed; all the learners answered both the qualitative and the quantitative aspects of the questions.

\subsection{Data collection}

Quantitative data was collected through the administration of a structured questionnaire distributed to the participants. In designing the questionnaire, factors raised in the previous study by Maile and Olowoyo (2017) which alluded to causes of late coming were used. The current study is based on the premise that the initial answers in the previous study were in a generalised format; however, the current study specifies and categorises which group (male or female) is mostly affected by each factor raised in the previous study. The participants were grouped according to their classes and also based on gender. In addition, each was provided with a questionnaire after a thorough explanation on the purpose of the research.

\subsection{Instrumentation}

The questionnaire consisted of twenty-two items to which participants responded using the Likert-scale. The responses were classified as follows: Strongly agree (SA), Agree (A), Neutral (N), Disagree (DA) and Not relevant (NR). The questionnaire was piloted with 10 respondents) before allowing others to participate to achieve its validation and the results were used to rephrase some of the items. Qualitative data was collected through semistructured interviews. 


\subsection{Data analysis}

Data was analysed using SPSS Version 25 on the basis of the key constructs investigated. Quantitative data was specifically analysed by using descriptive statistics while Atlas was used to analyse qualitative data. Differences in the reasons for lateness based on gender were analysed using the student t-test. Factors such as house chores, watching television, influence of peer pressures and the school management systems were considered. Qualitative data was arranged using axial coding and thematic themes which involve main ideas were grouped together to form themes (Cohen et al., 2007).

\subsection{Validity and reliability}

Validity refers to the integrity and application of the methods undertaken and the precision with which the findings accurately reflect the data, while reliability describes consistency within the employed analytical procedures (Noble \& Smith, 2015). The internal reliability of the instrument was evaluated by calculating Cronbach's alpha for each item. The average Cronbach's alpha value of 0.85 was obtained which signified an acceptable internal consistency of the instrument. The Cronbach's alpha is used as scale reliability or internal consistency indicator (Taber, 2017). This is the degree to which the items that make up the scale all measure the same underlying attribute. The trustworthiness of the study was ensured by allowing all the participants to express themselves freely without any potential bias or personal motivation from the researcher. Participants were allowed to freely relate how each of the factors mentioned under the quantitative aspect affected their decisions or actions regarding arriving at school late.

\section{Peer review}

There was an ongoing dialogue and critical reflection with other researchers on the research process and tentative interpretations.

\section{Reflexivity}

The researchers engaged in critical self-reflection regarding anything that may bias the interpretation of data, e.g. hidden assumptions, own worldview, theoretical orientation and interrelationships. Biases and assumptions were made explicit.

\section{Audit trails}

A detailed account of methods, procedures and reasons for decisions taken were provided.

\section{Rich description}

A detailed description of events was provided to enable readers to contextualize the study and judge the extent to which the findings could apply to their situations.

\section{Ethical considerations}

Approval to carry out the study was obtained from the District and Head Office of the Gauteng Department of Education and this was subsequently taken to the school principals before the commencement of the study. Before the interview 
consent was also sought from all the participants to use a recorder and their right to withdraw from the study at any stage was respected.

\section{Results}

The study examined factors influencing late coming of male and female learners at selected schools in Soshanguve Township. Related findings emanating from both quantitative and qualitative data are presented together. Quantitative data was collected through the administration of a survey questionnaire. The findings are categorised according to the key constructs investigated, namely household chores, school governance, scholar transport and distance, and peer pressure. Table 1 below provides the number of participants per grade at selected schools. The sample comprised more male learners $(65 \%)$ than female learners $(35 \%)$.

Table 1: Number of participants per grade at selected schools

\begin{tabular}{ccccc}
\hline Grade & Males & Percentage & Females & Percentage \\
\hline 12 & 13 & 16 & 6 & 7.5 \\
11 & 28 & 35 & 16 & 20 \\
10 & 11 & 14 & 6 & 7.5 \\
Total & 52 & 65 & 28 & 35 \\
\hline
\end{tabular}

Factors contributing to late coming in males and females

(a) Household chores and their impact on late coming

Table 2 provides a distribution of responses in relation to the performance of household chores as one of the factors influencing late coming.

Table 2: Late comers as a result of household chores from selected perpetual late comers

\begin{tabular}{lcccccc}
\hline \multicolumn{1}{c}{ Factors } & \multicolumn{2}{c}{ Grade 10 } & \multicolumn{2}{c}{ Grade 11 } & \multicolumn{2}{c}{ Grade 12 } \\
& Boys & Girls & Boys & Girls & Boys & Girls \\
\hline Washing of dishes & 8 & 6 & 15 & 16 & 4 & 6 \\
Cooking at home & 2 & 6 & 4 & 16 & 4 & 6 \\
Taking care of young siblings & 7 & 4 & 8 & 12 & 3 & 5 \\
Cleaning of the home & 9 & 6 & 7 & 14 & 5 & 6 \\
Watching television & 10 & 2 & 25 & 13 & 13 & 3 \\
Going to sleep late at night & 11 & 6 & 28 & 6 & 12 & 6 \\
Morning duties & 11 & 5 & 7 & 16 & 5 & 6 \\
\hline
\end{tabular}

A considerable number of male learners in grade 10 indicated that their late coming is due to factors such as watching television (91\%), going to sleep late at night $(100 \%)$ and performance of morning duties (100\%). Factors influencing late coming as indicated by the majority of female learners in grade 10 involved the performance of household chores such as washing dishes $(100 \%)$, cooking $(100 \%)$ and house cleaning $(100 \%)$. Predominant factors influencing late coming of the majority of male learners in grade 11 included washing of dishes $(63 \%)$, watching television (89\%) and going to sleep late at night (100\%). Female learners in Grade 11 were overwhelmed by involvement in activities such as washing of dishes $(100 \%)$, cooking $(100 \%)$, taking care of young ones $(75 \%)$, 
house cleaning (88\%), watching television $(81 \%)$ and morning duties $(100 \%)$. Predominant factors influencing late coming of the majority of male learners in grade 12 were watching television $(100 \%)$ and going to sleep late at night $(92 \%)$. In similar vein, female learners in grade 12 were overwhelmed by the performance of household chores.

Most male learners indicated that they went to bed late at night and this is positively correlated with watching television till late at night (0.99). One of the respondents said:

" sleep late at nights because there are some soapies that I need to watch and when I sleep late, I woke up very late and tired"

From the findings, the boys that participated in this study were not much involved in all household chores; the responsibility rested mostly on the shoulders of female learners. For instance, all female learners in grades 10, 11 and 12 indicated that cooking and cleaning were the most time-consuming activities at home. The t-test result obtained was 0.035 which revealed a significant difference at $p<0.05$ in terms of the effect of household chore activities between male and female learners (Table 3). A positive correlation (0.62) was also observed for watching television till late at night and going to sleep very late: this may be a key factor influencing the late coming of male learners. One of the boys interviewed mentioned the following:

"I don't do much of the jobs at home but usually busy on my phones or moving around with friends, I have sisters, they do it for me".

A female who responded says:

"I sleep late at nights do to household chores and cooking, my mum is late and we are not staying with our father, so I need to help my granny".

It should be pointed out that the findings in Table 2 with regard to household chores and management are limited to weekdays only and this might have influenced the lower numbers of female learners who indicated that they watched television. Few female learners reported that they watch TV till late at night and this corresponds well with the activities that must have consumed their time and energy in the evening.

Table 3: Comparing the effect of the household chores on late coming between the male and female learners

\begin{tabular}{lllll}
\hline Factors & Frequency & df & T value & P value \\
\hline Boys & 52 & 78 & 1.897 & 0.0308 \\
Girls & 28 & & & \\
\hline
\end{tabular}

(b) School governance, transportation and travelling distance as factors contributing to late coming

Table 4 provides a distribution of responses in relation to school governance, transportation and travelling distance as factors contributing to late coming. 
Table 4: Late comers that indicated school governance, transport and travelling distance as factors responsible for their late coming

\begin{tabular}{|c|c|c|c|c|c|c|}
\hline \multirow[t]{2}{*}{ Factors } & \multicolumn{2}{|c|}{ Grade 10} & \multicolumn{2}{|c|}{ Grade 11} & \multicolumn{2}{|c|}{ Grade 12} \\
\hline & Boys & Girls & Boys & Girls & Boys & Girls \\
\hline My house is far from school & 6 & 4 & 15 & 7 & 5 & 4 \\
\hline Waiting for transportation & 4 & 1 & 16 & 9 & 7 & 2 \\
\hline Trekking to school & 9 & 5 & 12 & 12 & 6 & 5 \\
\hline $\begin{array}{l}\text { Discouraged by the first } \\
\text { subject at school }\end{array}$ & 7 & 5 & 26 & 14 & 10 & 6 \\
\hline Discipline at school & 11 & 6 & 27 & 16 & 11 & 6 \\
\hline Teachers' attitude & 10 & 2 & 28 & 6 & 11 & 2 \\
\hline Homework load & 11 & 6 & 28 & 15 & 13 & 6 \\
\hline Weather during winter & 9 & 6 & 14 & 16 & 11 & 6 \\
\hline $\begin{array}{l}\text { Taking younger ones to } \\
\text { school }\end{array}$ & 3 & 2 & 2 & 11 & 4 & 5 \\
\hline
\end{tabular}

A considerable number of male learners in grade 10 highlighted discipline at school $(100 \%)$, teachers' attitude $(91 \%)$ and homework load $(100 \%)$ as factors influencing their late coming. Female learners in grade were largely affected by travelling to school $(67 \%)$, discipline at school $(100 \%)$ and being discouraged by the first subject featured on the time table at school $(83 \%)$. Late coming by male learners in grade 11 was affected by a variety of factors. These factors included travelling distance (53\%), mode of transport (57\%), discouragement by the first subject featured on the time table at school (93\%), discipline at school $(96 \%)$, teachers' attitudes $(100 \%)$, homework load $(100 \%)$, and weather conditions, particularly during the winter $(50 \%)$ season. The distribution of responses reflected a similar trend for female learners in grade 11.

Predominant factors influencing late coming by male learners in grade 12 included discouragement by the first subject featured on the time table at school $(77 \%)$, discipline at school $(85 \%)$, teachers' attitude (85\%), homework load $(100 \%)$, and weather conditions, particularly during winter season $(85 \%)$. The distribution of responses reflected a similar trend for female learners in grade 12. It must be pointed out that taking care of younger siblings in the family appeared to be a key factor influencing the late coming of female learners in both grades $11(75 \%)$ and grade $12(83 \%)$. This practical scenario can be attributed to the prevalence of child-headed households in the township. A respondent stated the following:

"The first subject of the day which is Mathematics is boring and I don't

even like the teacher, so if am late I don't care"

Another respondent mentioned the following:

"Even when you are late, you will just stay outside for few minutes and so no reason to rush".

Another indicated the following:

"I am a senior student now, no one can force me anymore"

Teachers' attitudes were more frequently reported by male learners than female learners. All the male learners in grades 10 and 11 reported that teachers' 
attitude is a major factor which causes late coming. Amongst the grade 12 learners, $85 \%$ of the male learners agreed that teachers' attitudes were a factor. Although $98 \%$ of the respondents agreed that this is a factor that led to late coming in high school, there was no significant difference in the responses received from boys and girls in this regard $(\mathrm{p}>0.05)$.

Table 5: Comparing the effect of teachers' attitude to late coming between male and female learners

\begin{tabular}{lllll}
\hline Factors & Frequency & df & T value & P value \\
\hline Boys & 52 & 78 & 0.247 & 0.4028 \\
Girls & 28 & & & \\
\hline
\end{tabular}

A female learner said:

"You will have to cook and assist at home and yet you still have lots and lots of homework, there is no way you won't sleep late and wake up very late. At times I do my homework in the morning and at times I just check and copy what others have done by the gate of the school."

The winter season is also viewed as a major problem because of the cold conditions when learners have to wake up very early and then wait for buses at bus stops. A total of $78 \%$ of the respondents agreed to this as a factor. However, there was no significant difference in the submissions received from boys and girls although the percentage of boys that agreed to winter as a factor were more than that of female learners (see Table 2).

The highlighted factors influencing late coming by learners in selected township schools underscore the need to put systems in place to alleviate concomitant structural problems impacting on the provision of quality education. The participants bemoaned the lack of discipline at school as it has an adverse impact on their studies, resulting in late coming becoming a pervasive problem as well. Maintenance of discipline appears to be a chronic governance challenge at township schools. It is incumbent on the school management teams to provide innovative leadership to create stimulating and dynamic learning environments, particularly at township schools. The realisation of this key strategic imperative broadly hinges to a large degree on a fundamental rethink of school governance policies with a view to bring about transformative change to school management practices.

(c) Peer pressure as a factor responsible for late coming

Table 6 below provides the distribution of responses on peer pressure as a factor responsible for late coming.

Table 6: Peer pressure

\begin{tabular}{lcccccc}
\hline \multicolumn{1}{c}{ Factors } & \multicolumn{2}{c}{ Grade 10 } & \multicolumn{2}{c}{ Grade 11 } & \multicolumn{2}{c}{ Grade 12 } \\
& Boys & Girls & Boys & Girls & Boys & Girls \\
\hline Waiting for friends & 10 & 5 & 26 & 12 & 11 & 6 \\
Smoking & 9 & 2 & 27 & 9 & 11 & 3 \\
Gambling & 5 & 1 & 11 & 5 & 5 & 1 \\
Working in groups & 3 & 5 & 6 & 4 & 4 & 5 \\
Chatting with friends & 7 & 6 & 15 & 13 & 8 & 6 \\
\hline
\end{tabular}

http://ijlter.org/index.php/ijlter 
As depicted in Table 6, peer pressure-related factors influencing the late coming of male and female learners in grades 10 to 12 included waiting for friends $(88 \%)$, smoking $(76 \%)$, gambling $(35 \%)$ and chatting with friends $(69 \%)$. Very few learners (both males and females) indicated working in groups as a factor that causes them to be late for school. It is interesting to note that late coming of female learners in grades 10 to 12 was not largely influenced by factors such as smoking and gambling. Smoking and gambling appeared to be a socio-cultural practice affecting learning activities of male learners at the selected township schools. The provision of appropriate psycho-social support by the Department of Basic Education is crucially important to foster conducive teaching and learning environments at such schools.

It was also observed that male learners were the group most affected. An important point to note is that there are usually cigarette sellers not far from the school gates and in some instances male learners would be observed loitering around the areas where they can buy cigarettes. Some of the learners indicated that there are also substances that learners smoke other than ordinary tobacco and cigarettes. These substances were mostly smoked after school in order to avoid the smell being detected by the teachers.

Some of the learners reported that some of their fellow learners, especially male learners, engaged in gambling activities outside the school gate early in the morning. This accounted for small groups of late comers. Female learners indicated that chatting with friends does not necessarily occur in the morning but mostly at homes and at night. As such, $89 \%$ of the female learners who participated in the study indicated that they chatted on their mobile phones until late after doing household chores and hence they went to bed late in most cases. However, only $58 \%$ of the boys indicated that they engaged in this same activity.

\section{Discussion}

Late coming of male and female learners at selected township schools was influenced by a myriad of contextual factors. These factors related to performance of household chores, school governance, mode of transport, travelling distance, and peer pressure. Predominant factors related to the late coming of male learners across the grades included watching television, hence going to sleep late at night and the performance of morning duties. Late coming of female learners across the grades was largely influenced by the performance of household chores such as washing dishes, cooking and house cleaning. The differences in the factors influencing the late coming of male and female learners across the grades appeared to be gender based. Adequate sleep in teens has been linked to overall academic success and improvements in memory, learning, and attention (Nahmod et al., 2017). Sufficient sleep in teens has also been linked to improved mood and health and decreased sports-tardiness and school dropouts. Teens that do not obtain an adequate amount of sleep are also more likely to smoke cigarettes, engage in sexual activity, and use marijuana (Hoedlmoser, 2020). Maile and Olowoyo (201) argued that learners who are overwhelmed by school work often go to sleep late at night. A study conducted by Jumare et al. (2015) highlighted a higher prevalence of late coming of female learners as compared to male learners. According to Parajuli and Thapa (2017), 
male learners tend to display higher levels of externalizing behaviours than girls. The nature of factors influencing late coming of female learners across the grades is consistent with the factors identified by a study conducted by Jumare et al. (2015).

Predominant factors related to school governance, transport and travelling distance influencing the late coming of learners across the grades included travelling distance, mode of transport, discouragement by the first subject featured on the time table at school, discipline at school, and teachers' attitude. Onoyase (2017) mentioned that location and distance proved to be key factors influencing the late coming of female learners. Anti-social behaviour is often related to the social complications associated with adolescent stage. Learners in the adolescent stage feel they have control over themselves and are clever enough to manufacture lies and decide on what their future should be with the aid of peer groups (Jumare et al., 2015). In addition, this stage is also associated with volatile emotions and boundary-testing behaviour as individuals explore and assert personal identity, learn to navigate peer relationships, and transition to independence (Moadab et al., 2017).

Peer pressure-related factors influencing the late coming of male and female learners in grades 10 to 12 included waiting for friends, smoking, gambling and chatting with friends. It is interesting to note that the late coming of female learners in grades 10 to 12 was not largely influenced by factors such as smoking and gambling. Smoking and gambling appeared to be socio-cultural practices affecting the learning activities of male learners at selected township schools. Jonathan et al. (2017) highlighted a negative attitude towards schooling, lack of strict discipline in school, and lack of parental monitoring as factors influencing the late coming of learners at schools. Parental involvement in their children's development has consistently been recognized as a key element that can promote the effectiveness of early childhood responsibility (Varshney et al., 2020). The nature of factors influencing late coming can be attributed to the exclusive complexity of social challenges facing male and female learners in society. The differences in the factors influencing the late coming of male and female learners within the context of this study may be attributed to cultural and ethnic considerations.

\section{Interpretation of key findings in terms of the adopted theoretical framework}

A critical analysis of key findings emanating from the study shows that there is lack of concerted efforts by parents, school management teams, the broader community and the Department of Basic Education to turn the tide against endemic late coming of learners at township schools. The leaner-centred ideology which puts the leaners at the centre showed that efforts should be geared towards understanding the cause of the lateness on the part of the leaners. The management, in this case the school and parents, should seek a way of assisting the learners. For instance, the classes could be made more interesting or accommodating so that the students would be willing to attend school and be on time. Drawing on the social efficiency theory, it shows that the learners do not have the requisite agency to acquire knowledge and skills to 
realise their full potential and key aspirations. Therefore, it is necessary for individuals to be knowledgeable about how they can attain their desired goals.

While learners made every effort to attend school against all odds, they lacked guidance, support, monitoring, and a conducive environment in the form of a home, society and the school for them to remain focused. An example is the issue of child-headed households, and problems with regard to travelling long distances to and from school, which expose these youngsters to a myriad of negative influences such as smoking and gambling. The adults tend to abdicate their responsibilities, thereby exposing the youngsters to negative social tendencies associated with peer pressure. School management teams find it extremely difficult to clamp down on the selling of cigarettes, narcotics and other harmful substances in the vicinity of the school environment. Proximity and access to narcotic substances have a detrimental impact on teaching and learning at township schools. No particular individual, civil group or government entity takes the responsibility to monitor or control the situation despite the teenage stage being a volatile phase in the life of youngsters (Moadab et al., 2017).

This paper argues that endemic late coming of learners at township schools can be alleviated through fundamental restructuring of policies governing the functioning of public schools. Endemic late coming of learners at township schools in particular has to be eradicated if meaningful human capital development is to become a reality for the fulfilment of societal and economic goals. Substantial progress made in the realisation of this key strategic imperative would pave the way for the provision of quality education within the broader South African context.

\section{Conclusion}

Late coming of male and female learners at township schools is influenced by a myriad of contextual factors. Major concerns in this study were the responses that workload (homework) for both males and female and household chores for females were major factors directly or indirectly causing late coming. The learners agreed that it is a direct factor because of the enormous amount of time they spent when completing their homework while the female learners agreed that the tasks at home were just too demanding. These and other factors appeared to be socio-cultural in nature. This key observation underscores the need for a comprehensive reconfiguration of the school governance policies to ensure that schools are not bedevilled by structural problems impinging on teaching and learning. In the final analysis, late coming remains a pervasive problem stifling the provision of quality education at township schools. Generally from this study, major issues confronting the students are multifaceted and include the management of household chores and the school management system. The social efficiency theory discussed in this work and student-centred learning, if adequately practised or implemented, will assist in reshaping or re-evaluating the traditional ways of doing things in the past, thereby allowing for restructuring which will ultimately mitigate the habit of coming late among some learners, if not all. 


\section{Recommendations arising from the study}

There is a critical need to put systems in place to alleviate concomitant structural problems impacting on the provision of quality education at township schools. Restoration and sustainable maintenance of discipline at township schools are crucial for coherent realisation of effective teaching and learning. There is a need to rethink school governance policies fundamentally in order to strengthen administrative management capacity at township schools. The Department of Basic Education faces the key imperative to provide the appropriate psychosocial support required for the effective functioning of schools.

\section{References}

Agboblie, D. K., \& Mensah, F. O. (2016). The perceived impact of lateness and absenteeism on students' performance. The cause of Huni Valley Senior High School. [Master's thesis University of Education, Winneba, Ghana]. http://ir.uew.edu.gh

Adegunju, K. A., Ola-Alani, E. K., \& Agubossi, L. A. (2019). Factors responsible for students' lateness to school as expressed by Nigerian teachers in elementary schools. Mimbar Sekolah Dasar, 6(2), 185-197.

Armend, T. (2017). Curriculum field in the making: Influences that led to social efficiency as dominant curriculum ideology in progressive era in the U.S. European Journal of Curriculum Studies, 4(1), 618-628.

Bailey, C. T. (2015). The production of schools: A critical investigation of capitalist and democractic struggles for social efficiency [Master's thesis, University of Texas, Austin, USA].

British Council. (2012). Gender in Nigeria Report 2012: Improving the lives of women and girls in Nigeria ( $2^{\text {nd }}$ ed.). British Council.

Chujor, J. C. (2014). Effects of counselling in curbing persistent lateness to school among university secondary students in River State, Nigeria. http://www.ijird.com.

Cohen, L., Manion, L., \& Morrison, K. (2007). Research methods in education (6 th $^{\text {th }}$ ed.). Routledge.

Consortium for Research into Educational Access, Transitions and Equity (CREATE) (2012). Reconceptualising access to education. Policy Brief Number 1, March 2008.

Department of Basic Education (DEB) (2009). Call for comment on the Learner Attendance Policy and Procedures, 2009. https://www.gov.za/sites/default/files/gcis_document/201409/32414982.pdf

De Lissovoy, N., Means, A., \& Saltman, K. (2014). Toward a new common school movement. Paradigm Publishers.

Equal Education. (2018). Late coming. https://equaleducation.org.za/campaigns/latecoming

Gay, L. R., Mills, G. E., \& Airasian. P. (2011). Educational research: Competencies for analysis and applications (10 $\quad$ ed. $)$. https://yulielearning.com/pluginfile.php/4831/mod_resource/content/1/Gay -E\%20Book\%20Educational\%20Research-2012.pdf

Hoedlmoser, K. (2020). Co-evolution of sleep spindles, learning and memory in children. Current Opinion in Behavioral Sciences, 33, 138-143. http://doi.org/10.1016/j.cobeha.2020.03.005

Humphreys, S., Moses, D., Kaibo, J., \& Dunne, M. (2015). Counted in and being out: Fluctuations in primary school and classroom attendance in Northern Nigeria. International Journal of Educational Development 44, 134-143. http://doi.org/10.1016/j.ijedudev.2015.08.004 
Jonathan, N. C., Amanze, S. U., Oladosu, O.T., \& Adewumi, T. (2017). Corporal punishment: Perceptions and adoption in Nigerian secondary schools. Education Research Journal, 7(8), 200-204. http://resjournals.com/journals/educationalresearch-journal.html

Jumare, A. M., Maina, B. A., \& Ankoma-Sey, V. R. (2015). Analysis on students' latecoming factors in selected secondary schools in Zaria: Implications for educational managers. Journal of Education and Practice, 6(32). https://core.ac.uk/download/pdf/234638136.pdf

Maile, S., \& Olowoyo, M. M. (2017). The causes of late coming among high school students in Soshanguve, Pretoria, South Africa. Pedagogical Research, 2(2), 4. https://doi.org/10.20897/pr/80951

McCrudden, M. T., Marchand, G., \& Schutz, P. (2019). Mixed methods in educational psychology. Contemporary Educational Psychology, 57, 1-8. http://doi.org/10.1016/j.cedpsych.2019.01.008

McKeever, P. M., \& Clark, L. (2017). Delayed high school start times later than 8:30am and impact on graduation rates and attendance rates. Sleep Health, 3(2), 119-125. http://doi.org/10.1016/j.sleh.2017.01.002

Moadab, G., Bliss-Moreau, E., Bauman, M. D., \& Amaral, D. G. (2017). Early amygdala or hippocampus damage influences adolescent female social behaviour during group formation. Behavioural Neuroscience, 131, 68-82. http://doi.org/10.1037/bne0000181

National Staff Reporter. (2016). It's not kids bunking - it's teachers. Mail \& Guardian (2 June). https:// mg.co.za/article/2016-06-02-its-not-kids-bunking-its-teachers

Nahmod, N., Lee, S., Buxton, O., Chang, A., \& Hale, L. (2017). High school start times after 8:30 am are associated with later wake times and longer time in bed among teens in a national urban cohort study. Sleep Health, 3(6), 444-450. http://doi.org/10.1016/j.sleh.2017.09.004

Ngubane, L. P., \& Mkhize S. M. (2018). Perception and experiences of learners on the banning of corporal punishment in South African Schools: A case study of four township schools in the Pinetown District of District of KwaZulu-Natal. (Doctoral dissertation, University of KwaZulu Natal, South Africa). http://www.ukzn.edu

Noble, H., \& Smith, J (2015). Issues of validity and reliability in qualitative research. Evidence Based Nursing 18, 2-4. http:// doi.org/10.1136/eb-2015-102054

Nonkonana, T. G., \& Kwenda, D. C. (2020). Strategies used by the School Management Team in managing learners' late coming in a Cape Town high school [Master's dissertation, Cape Peninsula University, Cape Town, South Africa]. http://etd.cput.ac.za/handle/20.500.11838/3039

OECD (2013), PISA 2012 Results: What Makes Schools Successful (Volume IV): Resources, Policies and Practices, PISA, OECD Publishing, Paris, https://dx.doi.org/10.1787/9789264201156-en.

Oghuvbu, E. P. (2012). Attendance and academic performance of students in secondary schools: A correlational approach. Study at Home Communication Science, 4, 21-25. http://doi.org/10.1080/09737189.2010.11885294.

Onoyase, A. 2016. Lateness: A recurrent problem among secondary school students in Akoko South East Local Government Area of Ondo, State Nigeria. Implications for counselling. Higher Education Studies, 7(1), 107-113. http://doi.org/10.5539/hes.v7n1p107

South African Broadcasting Corporation (SABC) (2016). Morning live news on the 14/07 2016. 
Sultana, A. M., \& Rashid, S. N. B. (2013). A study on time management and punctuality issues among students at secondary school, Kedah. American Journal of Economics, 3(5), 52-56. http://doi.org/10.5923/c.economics.201301.10

Swedberg, R. (2018). On the uses of exploratory research and exploratory studies in Social Sciences. In J. Gerring, C. Elman \& J. Mahoney (Eds.), Producing knowledge. Cambridge University Press.

Taber, K. (2017). The use of Cronbach's alpha when developing and reporting research in instruments in science education. Research in Science Education.

UNICEF. (2012). Girls Education Project (GEPII). Northern Nigerian end of project assessment. UNICEF.

Varshney, N., Lee, S., Temple, J.A., \& Reynolds A.J. (2020). Does early childhood education enhance parental school involvement in second grade? Evidence from Midwest Child-Parent Center Program. Children and Youth Services Review, 117, 105317. http://doi.org/10.1016/j.childyouth.2020.105317

Warne, M., Svensson, Å., Tirén, L., \& Wall, E. (2020). On time: A qualitative study of Swedish students', parents' and teachers' views on school attendance, with a focus on tardiness. International Journal of Environmental Research and Public Health, 17(4), 1430. http:// doi.org/10.3390/ijerph17041430

Whole School Evaluation Policy. (2002). The National Policy on Whole-School Evaluation. Government Gazette, 433(22512) of July 2001. https://www.education.gov.za/Portals/0/Documents/Publications 